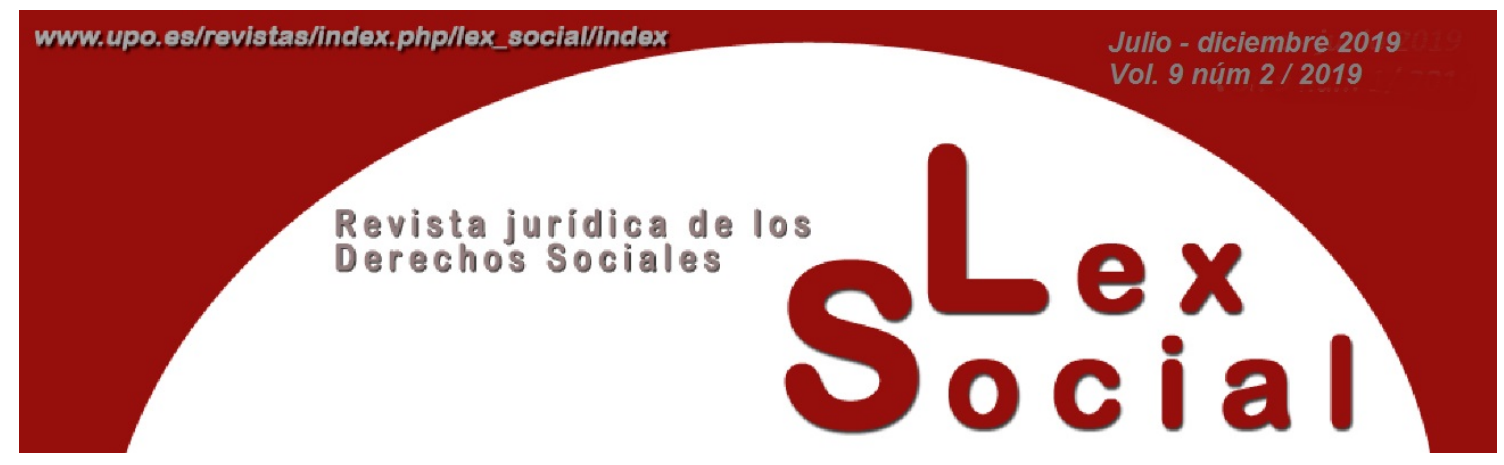

\title{
UN ASPECTO JURÍDICO ESPECIALMENTE PROBLEMÁTICO: LA EXTINCIÓN DE LA RELACIÓN LABORAL
}

\section{A SPECIFICALLY PROBLEMATIC JURIDICAL ASPECT: THE EXTINCTION OF THE LABOR RELATIONSHIP}

\author{
$M^{a}$ INMACULADA BENAVENTE TORRES \\ Derecho del Trabajo y de la Seguridad Social \\ Universidad de Córdoba
}

Artículo recibido el 10 de mayo de 2019

Artículo aceptado el 27 de mayo de 2019

\begin{abstract}
RESUMEN
La Disposición Adicional 2a.2.1 ${ }^{\text {a }}$ RD. 1620/2011, 14-11 dejó pendiente la valoración de la posibilidad de aplicar plenamente el régimen común de la extinción a la relación laboral especial del servicio del hogar familiar, así como de incluir el desistimiento del empleador en alguna de las causas comunes del art. 49 ET. El presente estudio aborda el régimen jurídico de la extinción del contrato de trabajo en esta relación laboral especial tratando, en cierto modo, de dar respuesta a tales cuestiones, así como de identificar los principales déficits exegéticos y de regulación de dicha norma.
\end{abstract}

Palabras Clave: Trabajador del hogar familiar, relación laboral especial, derechos fundamentales, desistimiento, extinción, despido.

\section{Abstract}

The additional Provision $2^{\mathrm{a}} \cdot 2 \cdot 1^{\mathrm{a}}$ RD. 1620/2011, 14-11 left pending the evaluation of the possibility of applying fully the common regime of the extinction to the special labor relation of the service of the family home, as well as to include the 
withdrawal of the employer in any of the common causes of the . 49 ET. The present study addresses the legal regime of the termination of the employment contract in this special employment relationship trying, in a certain way, to respond to such questions, as well as to identify the main exegetical deficits and of regulation of said norm

KEYWORDS: Worker of the family home, special employment relationship, fundamental rights, extinction, withdrawal, dismissal.

\section{SUMARIO}

1. Introducción.

2. Es muy difícil alcanzar una auténtica homogeneidad en la extinción de la relación especial del hogar familiar.

3. El desistimiento.

4. El despido disciplinario mantiene una línea continuista respecto del anterior con mejoras en la cuantía de la indemnización.

5. El punto más débil y criticable radica en el desistimiento indemnizado del trabajador.

6. Bibliografía.

\section{INTRODUCCIÓN}

Dejando ahora al margen la evolución histórica de la regulación del trabajo doméstico en España, puede decirse que el régimen jurídico propio de la extinción de la relación laboral del servicio del hogar familiar es la especialidad más destacable y polémica de esta regulación especial desde su plena laboralización. Bien es verdad que el actual RD. 1620/2011, de 14 de noviembre, por el que se regula la relación laboral de carácter especial del servicio del hogar familiar (BOE núm. 277, de 17/11/2011) ha eliminado o suavizado muchas de las peculiaridades que recogía el precedente RD. 1424/85, de 1 de agosto (BOE núm. 193, de 13 de agosto de 1985), en una tendencia homogeneizadora, en la medida de lo posible, con el régimen laboral común. Pero la extinción de la relación laboral, aun siendo rectificada en un sentido más tutelar del trabajador, sigue manteniendo su característica clave, cual es la figura del desistimiento acausal de la relación por parte del empleador. Además, y pese a que como decimos, la reforma ha alcanzado a la extinción del contrato, puede anticiparse que lo ha hecho de forma insuficiente, al menos en consideración a la regulación del desistimiento del trabajador. 
Por otra parte, los aspectos más sustantivos de las modificaciones introducidas, o, al menos, las que pudiesen interpretarse como tales, aparecen haber pasado en cierto modo desapercibidos, ocultados por una tendencia al continuismo exegético basado en una jurisprudencia del Tribunal Supremo que sólo tenía sentido bajo el precedente RD. 1424/85, pero que ahora habría que, como de hecho se está haciendo, reevaluar.

No es usual comenzar un estudio doctrinal a partir de sus conclusiones principales. Sin embargo, dado que este artículo tuvo como origen mi participación en el Seminario Permanente del Trabajo Doméstico, he optado por seguir aquí el mismo estilo que adopté entonces en mi intervención. Repárese que en la Disposición Adicional $2^{\mathrm{a}} \cdot 2 \cdot 1^{\mathrm{a}}$ RD. 1620/2011, 14-11 se deja pendiente la valoración por un grupo de expertos de:

$<<$ La viabilidad de aplicar plenamente el régimen de extinción del contrato de trabajo de la relación laboral común establecido en el Estatuto de los Trabajadores a la relación laboral de carácter especial del servicio del hogar familiar, así como la posibilidad de incluir el desistimiento del empleador, entendido como pérdida de confianza en el empleado, en alguna de las causas comunes de extinción del contrato de trabajo establecidas en el at. 49 del Estatuto de los Trabajadores $>>$.

Pues bien, dado que ese trabajo aún está pendiente -y superado con creces el plazo previsto de 31-12-2012- pensé entonces que organizar mi intervención en el referido Seminario en torno a las conclusiones que alcanzase, podría ser un sistema muy práctico, simple y clarificador para servir como aportación a nuestro grupo de trabajo. Entonces, ¿cuáles son esas conclusiones provisionales?.

I. Es muy difícil alcanzar una auténtica homogeneidad en la extinción de la relación especial del hogar familiar por varios motivos:

1. Ni puede desaparecer el desistimiento en esta relación laboral especial;

2. Ni puede extenderse el desistimiento a las relaciones comunes;

3. Ni pueden desempeñar las causas comunes de extinción distintas del despido disciplinario un papel relevante en esta relación laboral especial.

II. El desistimiento

1. Presenta diferencias ostensibles frente a la extinción en el período de prueba que deberían excluir la aplicación de una idéntica doctrina respecto del art. 55.5 y 53.4 ET.

2. Ha sido mejorado en cuantía indemnizatoria y en seguridad jurídica en cuanto se han incrementado las exigencias formales y ha identificado los efectos de su incumplimiento. Tanto es así, que ahora puede defenderse que la forma del desistimiento es constitutiva.

III. El despido disciplinario mantiene una línea continuista respecto del anterior con mejoras en la cuantía de la indemnización. 
IV. El punto más débil y criticable de el régimen jurídico de la extinción en esta relación laboral especial radica en el desistimiento indemnizado del trabajador, que sigue sin regularse salvo, con claridad, en el supuesto de cambio de residencia a otra localidad. Por consiguiente, en el común de los casos las facultades extintivas del trabajador se limitan a la dimisión o abandono, y a la extinción basada en el incumplimiento del empresario por aplicación subsidiaria del art. 50 ET, huérfana también de tratamiento específico incluso para el interno. Esto último es particularmente grave y, aun más, en atención a que sí se prevé un supuesto de subrogación empresarial en el que, aparentemente, no se deja margen de desistimiento al trabajador.

Pasemos a desarrollar cado uno de estos postulados

\section{ES MUY DIFÍCIL ALCANZAR UNA AUTÉNTICA HOMOGENEIDAD EN LA EXTINCIÓN DE LA RELACIÓN ESPECIAL DEL TRABAJO DEL HOGAR FAMILIAR}

a. No puede desaparecer el desistimiento en esta relación laboral especial

Es evidente que el contexto del trabajo del hogar familiar ha cambiado ostensiblemente en la última década. Tanto es así que parece obligado cuestionar la especialidad de la prestación de servicios domésticos, una vez que esas mismas labores se vienen realizando bajo el régimen laboral común a través de la intervención de ETTs, como de empresas y cooperativas. También, por ejemplo, fuerza esta revisión la intensiva utilización de los profesionales de la ayuda a domicilio contratados en el marco de la Ley 39/2006, de 14 de diciembre, de Promoción de la Autonomía Personal y Atención a las personas en situación de dependencia (BOE núm. 299, de 15/12/2006). Si realizan el mismo trabajo, ¿qué justificación tiene su especialidad?, ¿Podría eliminarse el desistimiento y someter la relación a las causas comunes de extinción sin más?.

Eso es lo que parece cuestionar el legislador en la Disposición Adicional 2a $2 \cdot 1^{\mathrm{a}} \mathrm{RD}$. 1620/2011, 14-11, que hemos reproducido al comienzo. ¿Sería viable aplicar plenamente el régimen de extinción del contrato de trabajo de la relación laboral común? ¿Sería posible reconducir el desistimiento del empleador a la extinción común por pérdida de confianza en el empleado del art. 49 ET?. En mi opinión, no es posible ni conveniente.

Las razones de la especialidad de la regulación del servicio doméstico siempre han respondido a dos realidades intensamente interrelacionadas. Una, el lugar y objeto de la prestación, que es el hogar y quienes lo habitan, lo que es tanto como decir que es un lugar indisolublemente unido al derecho fundamental a la intimidad personal y familiar -y derechos conexos del honor y propia imagen- y a la inviolabilidad del domicilio del art. 18.1 y 2 CE. Otro, la especial relación de confianza que se establece y que es 
exigible entre empleador y empleado y sin cuyo sustento, una vez rota, hace que no pueda imponerse a ninguna de las partes su continuidad.

En su momento, la especialidad de la relación laboral del servicio doméstico se llegó a calificar por el Tribunal Constitucional de incuestionable en su STC 26/1984, 24-2 ${ }^{1}$, y reproduce la STC. núm. 268/1993, de 20 septiembre. También el Convenio OIT nº 189 y su Recomendación 201 parten de la indiscutible especialidad del trabajo doméstico y si bien están ambos instrumentos claramente direccionados a la protección del trabajador, en ningún momento se hace referencia a más límite en la extinción de la relación que al preaviso (ej. art. 7 COIT 189 y apartado 18 Recomendación). Posibilidad de exclusión de dicha categoría de trabajadores expresamente admitida respecto de la aplicación del Convenio $\mathrm{n}^{0} 158$ OIT, y efectuada por el grueso de los países que lo han ratificado ${ }^{2}$.

Resulta muy llamativo que el Tribunal Constitucional se haya expresado en términos tajantes, desacreditando cualquier intento de discusión, sin alusión siquiera, por evidentes, de esas razones que hacen del trabajo doméstico algo tan especial. En mi opinión y en lo que lo que a nosotros nos atañe, es decir, en el campo de la extinción del contrato, la figura del desistimiento y de la no readmisión en la improcedencia y nulidad del despido pueden valorarse como algo no sólo razonable sino, por las razones que seguidamente expondré, relativamente necesario desde una perspectiva constitucional. Hay desde luego otro importante motivo para negar esa posibilidad de readmisión cual es la prevención de las readmisiones fraudulentas.

Pues bien, desde esa perspectiva constitucional, considero que el desistimiento no debe desaparecer porque, como he anticipado, no puede imponerse el mantenimiento del trabajo en el hogar familiar. Es claro que no puede imponerse en particular al empleador pero, repárese, tampoco al empleado; también éste puede verse también afectado en su intimidad, muy en especial si es interno -vid. art. 6 Convenio OIT 189- ${ }^{3}$. Tampoco puede hacerse excesivamente gravoso para el común de los ciudadanos el prescindir de los servicios del empleado doméstico. En cuanto son derechos fundamentales, es legítima la prevalencia de los derechos del empleador frente a los derechos laborales del trabajador. De ahí la razón jurídica de la figura del desistimiento, como que no haya opción de readmisión en el despido improcedente o en el despido nulo. También desde esta perspectiva se justifica una indemnización inferior a la común, en tanto una alta indemnización podría suponer un límite desproporcionado al ejercicio de un derecho instrumental a los del art. 18 CE. Por consiguiente, la menor indemnización, también en el despido improcedente, se podría considerar, no obedece sólo a su desvaloración

\footnotetext{
${ }^{1}<<\ldots$ y en el caso que se resuelve no parece que sea menester utilizar mayor esfuerzo dialéctico para poner de relieve la realidad de la singularidad del tipo de trabajo doméstico, lo que no puede seriamente ponerse en duda. $>>$

2 OIT, "Nota sobre el Convenio núm. 158 y la Recomendación núm. 166 sobre terminación de la relación de trabajo”, pág. 19.

${ }^{3}$ Estas razones se retoman en el V epígrafe.
} 
social $^{4}$, o a la ausencia de plusvalía, o a que la relación se desenvuelve fuera del ámbito mercantil y con una presunta menor capacidad económica del empleador. Es que tampoco se puede elevar al extremo de hacer inoperante o muy gravoso el ejercicio del derecho fundamental implicado ${ }^{5}$.

Consiguientemente, equiparar la extinción de la relación especial a cualquier otro despido disciplinario del art. 54.1.d) ET, que por lo demás exige prueba, gravedad y culpabilidad $^{6}$, sería obviar desproporcionadamente la dimensión constitucional que tiene como trasfondo el desistimiento, a más señas indemnizado. Por otra parte, equiparar en indemnización a este empleador con el empresario mercantil podría suponer, habida cuenta de su específica causa contractual, como del diferente contexto económico y sociológico, un límite desproporcionado al ejercicio de un derecho instrumental a los del art. $18 \mathrm{CE}$.

Finalmente, es un error partir de que el desistimiento tiene por causa la pérdida de confianza, justificada objetiva o subjetivamente. Por el contrario, el desistimiento del empresario es acausal, y viene a cubrir no sólo la difícil acreditación de las bases de una pérdida de confianza, eludiendo las dificultades formales, de prueba y, en su caso, indemnizatorias, de un despido disciplinario. Por el contrario, y como comprobaremos más adelante, el desistimiento cumple una transcendente función en cobertura de los vacíos que deja la imposibilidad o dificultad de usar el grueso de las restantes causas de extinción unilateral.

b. No puede extenderse el desistimiento a las restantes relaciones que tengan por objeto el trabajo en el hogar familiar

Continuando con nuestra duda a la vista de las nuevas prestaciones de trabajo doméstico sometidas al régimen común, ¿deberían de alguna forma extenderse a estos otros supuestos en los que también está o puede estar en cuestión la intimidad del domicilio y vida privada, íntima -y hasta corporal- y familiar de los destinatarios de los servicios?.

Si las razones de la especialidad son las expuestas arriba, entonces deben derivarse al régimen común las prestaciones de servicios en el hogar familiar en las que el empleador sea una persona jurídica, una ETT, una institución pública o entidad privada.

\footnotetext{
${ }^{4}$ Por todos: GARRIDO PÉREZ, E., "El trabajo en el hogar: un replanteamiento de su especialidad desde el punto de vista normativo y jurisprudencial”, Mujer y Trabajo, Bomarzo, Albacete, 2003, pág. 250.

${ }^{5}$ En contra, defienden la causalización del desistimiento o el endurecimiento y equiparación de las sanción por despido improcedente e incluso la imposición -o, en su defecto, indemnización- de readmisión al menos en el despido nulo, por ejemplo: SALA FRANCO, T., "La relación laboral especial del Servicio del Hogar Familiar y el contrato de trabajo doméstico", Relaciones Laborales, 1986, Tomo I, pág. 313; LÓPEZ GANDÍA, J./TOSCANI GIMÉNEZ, D., El nuevo régimen laboral y de Seguridad Social de los trabajadores al servicio del hogar familiar, Bomarzo, Albacete, 2012, págs. 54 a 57.

${ }^{6}$ Es ajustado a derecho el despido por transgresión de la buena fe contractual prevista en el art. 54 ET, grave y culpable, por desobedecer la orden expresa de no sacar del hogar familiar efectos o enseres con la finalidad de entregarlos a su marido sin avisar previamente a la empleadora, en un caso de separación con violencia de género en que aquél se vio obligado a abandonar el domicilio por la guardia civil (STSJ. de Galicia de 6 marzo 2018, rec. 5376/2017).
} 
Así se hacía por el RD precedente y se hace ahora también en el art. 2 RD. 1620/2011. En tales casos carece de justificación tanto constitucional como económica la especialidad del desistimiento como las relativas al despido improcedente y nulo. Otra cuestión es que el cliente o usuario pudiese desistirse del contrato que le vinculase a la correspondiente empresa, o de alguna manera pudiese seleccionar al trabajador puesto a su servicio. Pero esa no es cuestión que aquí debamos tratar, con lo que nos limitaremos a señalar que las preferencias del cliente tendrán siempre como límite los derechos fundamentales y, señaladamente, la prohibición de discriminación.

c. Ni pueden desempeñar las causas comunes de extinción distintas del despido disciplinario un papel relevante en esta relación laboral especial

Ya lo he anticipado. Las restantes causas de extinción unilateral tienen un reducidísimo papel con lo que no parece que sea fácil esa "viabilidad de aplicar plenamente el régimen de extinción del contrato de trabajo de la relación laboral común” a que se refiere la Disp. Adic. 2 ${ }^{\text {a }}$.2.1 RD. 1620/2011.

1. En primer lugar, el art. 11.1 RD 1620/2011 excluye, tal y como hacía el anterior reglamento, las causas de fuerza mayor, -despido colectivo fundado en- causas económicas, técnicas, organizativas o de producción, así como por causas objetivas. En definitiva, se excluye la aplicación de los arts. 51, 52 y 53 ET, según expone el propio art. 11.1, por la incompatibilidad de tales causas con la naturaleza propia de esta relación laboral. Por consiguiente, ahora como antes, sólo cabe la extinción unilateral por desistimiento o por despido disciplinario.

Efectivamente, no parece que las causas económicas, técnicas, organizativas o de producción puedan sin más trasladarse al trabajo del hogar familiar porque conforme a su configuración estatutaria son esencialmente mercantiles ${ }^{7}$. Y lo mismo cabría decir del art. 52. e) ET. Por otra parte, volveríamos de nuevo sobre la idea de la imposible imposición de la relación y la desproporción en los sacrificios si se equipara a un empresario común en la improcedencia y los requisitos formales.

No obstante, como crítica cabría reseñar que la Directiva 98/59/CE, de 20-7-1998, relativa a la aproximación de las legislaciones de los Estados miembros que se refieren a los despidos colectivos no recoge en su articulado excepción alguna respecto de su aplicación al personal del hogar familiar (vid. art. 1.2 Directiva 98/59). Por consiguiente, y puesto que la Directiva ha eludido la configuración positiva de la causa de la extinción (<<causa no inherente a la persona del trabajador $>>$ ), la exclusión de estos despidos del procedimiento de despido colectivo que exige aquélla carece de amparo, pese a haber sido considerado como razonable dado que las exigencias numéricas que recoge la misma harían prácticamente inútil su previsión y su posible uso

\footnotetext{
${ }^{7}$ GARRIDO PÉREZ, E., “El trabajo en el hogar...”, cit., pág. 240.
} 
absolutamente marginal $^{8}$. No obstante, repárese que no resultaría tan excepcional su aplicación si se le extendiesen las exigencias numéricas del art. 51 ET, siendo más que cuestionable la fijación en tales condiciones de unos criterios numéricos diferentes para estos trabajadores en relación con una exigencia meramente procedimental.

En cuanto a las restantes causas del despido objetivo, en un primer acercamiento podría pensarse que son perfectamente trasladables a esta relación las causas de fuerza mayor como las de ineptitud sobrevenida, la falta de adaptación del trabajador a las modificaciones técnicas del puesto de trabajo, así como las faltas de asistencia al trabajo. Estas consideraciones han dado paso a que un sector doctrinal justifique dicha inaplicación por una cuestión de mera conveniencia; no habría una incompatibilidad real sino tan sólo la reconducción de las extinciones fundadas en dichas causas al libre desistimiento, menos oneroso y de procedimiento más sencillo ${ }^{9}$. Ahora bien, también podría apreciarse que son efectivamente incompatibles en tanto que el contexto de las mismas, en definitiva, los límites tutelares de aquéllas, que contribuyen en última instancia también a su definición, no tienen sentido -en particular- una vez que se admite el desistimiento, como tal acausal y con una indemnización inferior. Por ejemplo, ¿Es razonable exigir un curso de formación con cargo a dicho empleador así como el lapso de inmunidad de dos meses?. Y ¿qué modificaciones técnicas serían esas?; ¿sería verdaderamente un supuesto general o sumamente excepcional?. ¿Es, por ejemplo, razonable exigir un $20 \%$ de faltas de asistencia justificadas?. Todo parece indicar que el empleador doméstico carece, como regla general, de la capacidad de reorganización de un empresario ante las ausencias de un trabajador. En definitiva, todas estas causas, también las dificultades económicas que pudiesen afectar al empleador y las derivadas de fuerza mayor, tendrían que articularse a través de un desistimiento indemnizado, y por tanto, a través de un procedimiento mucho más sencillo y una indemnización más "sostenible” para el amo o ama de casa que, además, no se ve en ningún caso "auxiliado” por el FOGASA (art. 3.b) RD. 1620/2011) ${ }^{10}$ y responde con sus bienes personales.

\footnotetext{
${ }^{8}$ CRUZ VILLALÓN, J., "La aplicación de la Directiva sobre despidos colectivos”, Temas Laborales, $\mathrm{n}^{\circ}$, 44, 1997, pág. 37.

${ }^{9}$ Por todos: En este sentido, por ejemplo: GARRIDO PÉREZ, E., "El trabajo en el hogar ...", cit, pág. 250; ROMERO MIRET, P., La relación laboral especial y régimen de protección social del servicio del hogar, Tesis doctoral, dir. García Ortega, J./Ruano Albertos, S., Universidad de Valencia, 2016, págs. 260 a 262.

${ }^{10}$ En este sentido, destacando además que no tendría sentido imponer una indemnización por extinción por fuerza mayor o, más ampliamente, por causas objetivas, superior a la del desistimiento acausal: AYALA DEL PINO, C., Cuestiones laborales de la relación laboral especial de servicio del hogar familiar, Laborum, Murcia, 2005, págs. 215 y 216. También una crítica a la exclusión de la protección por el FOGASA, en tanto supone un perjuicio del trabajador en la protección frente a la insolvencia del empleador en: BARCELÓN COBEDO, S., "La relación laboral del servicio del hogar familiar tras el RD. 1620/2011, de 14 de noviembre”, Revista Doctrinal Aranzadi Social num.1/2012 parte Estudio, BIB $2012 \backslash 512$.
} 
2. En segundo lugar, el art. 11.1 RD. 1620/2011, extiende, conforme a lo previsto en dicho RD, todas las causas previstas en el art. $49 \mathrm{ET}$, excepto las que hemos visto señaladas en las letras h), i) y l) de dicho art. 49.1 ET. ¿Cuál es la dimensión real de tales causas en esta relación laboral?.

Por un lado, aun cuando parezca, a diferencia de la regulación precedente, que la remisión al art. 49 ET supone la novedosa integración de la jubilación del empleador y la de pérdida de la personalidad jurídica (art. 49.1.g) ET), es obvio que no son posibles ninguna de las dos. No cabe esta última figura extintiva por estar excluido este tipo de empresario (art. 3.b) RD 1620/2011). Tampoco cabe la primera puesto que no es posible jubilarse como tal empleador en el hogar familiar, dado que no es una actividad profesional que justifique su inclusión en el Sistema ${ }^{11}$. Además, la violencia de género como causa de extinción, que por razones obvias no podía estar prevista en el RD. 1424/1985, al introducirse en el art. 49.m) por la LOVG (Ley orgánica de violencia de género de 29-12-2004, ap. $5^{\circ}$ Disp. Adic. $7^{\mathrm{a}}$ ), debía entenderse aplicable ex Disp. Adic. de dicho reglamento. Repárese, no obstante, que en principio tiene una virtualidad muy relativa, al no generar esta relación especial derecho a prestación por desempleo.

Por otra parte, las causas de extinción por muerte o incapacidad del empresario también tienen un reducidísimo ámbito en esta relación laboral especial. De hecho, en el grueso de los supuestos examinados la opción extintiva ha sido la del desistimiento (o, en casos verdaderamente lacerantes, el despido disciplinario) ${ }^{12}$, realizado normalmente por familiares del empleador, en los supuestos de incapacidad, bien como guardadores de hecho, bien con tutores, bien, en caso de fallecimiento, como herederos del empleador. Repárese que del examen de los litigios sobre estas causas extintivas dejan en evidencia dos cosas: a) en estos supuestos es donde se hace más visible la labilidad o directamente incertidumbre sobre la figura del empleador; b) normalmente se opta por el desistimiento y no por usar estas causas extintivas, incluso aun cuando en relaciones laborales de larga duración pueden resultar éstas últimas más económicas al proceder una indemnización alternativa de un mes de salario -incluyendo la prorrata de pagas extras- y sin necesidad de preaviso alguno ni forma particular. En mi opinión esta situación se debe a que el desistimiento ha venido a cumplir la función de cubrir las lagunas e incertidumbres que provocarían la aplicación en esta relación laboral especial de las causas de extinción conforme se aplican en la relación laboral común. Veamos por qué.

\footnotetext{
${ }^{11}$ CORDERO GORDILLO, V., La relación laboral especial del servicio del hogar familiar, Tirant lo Blanch, Valencia, 2014, pág. 70; GARCÍA VIÑA, J., Aspectos laborales de salud laboral y de Seguridad Social de los empleados del hogar, Comares, Granada, 2009, pág. 96; QUESADA SEGURA, R., El contrato de servicio doméstico, Madrid, La Ley, 1991, pág. 196.

${ }^{12}$ Despido disciplinario realizado por los familiares guardadores de hecho de la anciana por maltrato y expolio económico, en beneficio del presunto incapaz (arts. 303 y 304 CCivil), declarada posteriormente su incapacidad judicialmente (STSJ. de Cataluña núm. 3050/2017, de 12 mayo, rec. 1403/2017). También, despido realizado por sobrino en nombre de su anciano tío, ante el expolio que sufre este último: STSJ. de Cataluña, núm. 286/2019 de 22 enero, rec. 5533/2018.
} 
En los casos de fallecimiento, ciertamente, y siempre y cuando el empleador fuese el fallecido teóricamente podría seguirse en un plazo prudencial tras la muerte, esta modalidad extintiva. El plazo es verdaderamente breve, pues en principio se reduce por el art. 10.1 RD 1620/2011 a tan sólo 7 días para la elusión de la subrogación ${ }^{13}$. No, en cambio, en los supuestos en que verdaderamente el empleador es el familiar, resida o no en el domicilio, que contrata los servicios para el cuidado del enfermo o anciano fallecido ${ }^{14}$. Por consiguiente, para la correcta utilización de esta causa es necesario con carácter previo distinguir cuándo se actúa en nombre de otro, y cuando se hace en nombre propio ${ }^{15}$. Por otra parte, la incertidumbre sobre quién sea el empleador alcanza también a los posibles supuestos en los que pudiese apreciarse una cotitularidad de la relación, por ejemplo, de tratarse de un matrimonio en sociedad de gananciales, atendidos ambos en los cuidados personales y del hogar y con similar capacidad directiva o de gestión. En mi opinión, ni tan siquiera en los supuestos de matrimonio y divorcio puede apreciarse una línea judicial unívoca y clara ${ }^{16}$. En los grupos

\footnotetext{
${ }^{13}$ No se califica de improcedente el despido realizado por hijo que no convivía en el hogar familiar y que tras el fallecimiento de sus padres requiere a la empleada para que le entregue las llaves de la casa: los empleadores eran sus padres, cuyas capacidades mentales no estaban mermadas (STSJ. Cataluña núm. 272/2014, de 16 enero, rec. 5136/2013).

${ }^{14}$ Un ejemplo en que la sobrina es la empleadora de los servicios que se prestan a su tía: STSJ. de Madrid núm. 292/2017, de 27 marzo, rec. 99/2017. En cambio, otro ejemplo, en que se contrata verbalmente por familiar y se considera empleadora a la que efectivamente recibe los servicios: STSJ. de Asturias núm. 9/2017, de 17 enero, rec. 2643/2016.

La cuestión ha dado lugar, junto con otros datos relevantes, a la calificación de la relación en algún supuesto dudoso. En este sentido, la STSJ. de País Vasco, núm. 1605/2004, de 1 septiembre, rec. 1303/2004, declara que es relación ordinaria y no especial la de salir a pasear con un anciano ingresado en una residencia, pues ni se desenvuelve el trabajo en el hogar familiar, dado que en el caso la habitación no es asimilable a ello, ni los que han contratado los servicios (hermanos y sobrinos) son los titulares del hogar familiar pues no residen en él, sin que conste que hayan actuado en representación de aquél.

${ }^{15}$ Por ejemplo, considera que el hijo contrata y despide como tutor en nombre de su madre incapacitada, siendo la titular y empleadora la madre, y ésta, por tanto, la que deba responder con sus bienes y no su hijo: STSJ. C. Valenciana, núm. 394/2019 de 12 febrero, rec. 3700/2018. También hay desistimiento realizado por familiares representantes con poderes otorgados por hermana de cognición muy deteriorada: STSJ de Castilla y León, Burgos, núm. 4/2019 de 17 enero, rec. 900/2018.

${ }^{16}$ Por ejemplo, hay condena de la mujer divorciada al tiempo de la extinción del contrato que celebró su marido con inmigrante sin permiso de trabajo: STSJ. de Murcia núm. 655/2012, de 17 septiembre, rec. 590/2012. También hay dos empleadores y responsabilidad solidaria -que no litisconsorcio pasivo necesario- de los excónyuges respecto de una sola relación laboral, que los vincula con la trabajadora que presta servicios en ambos domicilios en función de quién de ellos tenga los niños: STSJ. de Valladolid núm. 12/2018, de 29 enero, rec. 596/2017. En cambio, no es responsable la esposa del empleador cabeza de familia que tras su divorcio despide a la empleada de hogar. Este era el único empleador, que fue el que la contrató, le pagaba y abonaba las cuotas a la SS. Considera la sentencia que no se ha producido subrogación y que el empleador sigue siendo el exmarido aun cuando los servicios se hayan continuado prestando en la casa donde ya no reside él -según parece durante unos tres meses-: STSJ. de Madrid núm. 325/2011, de 9 mayo, rec. 6441/2010. También conforme a la STSJ. de Cataluña núm. 7190/2005, de 27 septiembre, rec. 4141/2005, no hay litisconsorcio pasivo necesario del matrimonio, pues nada hay que indique su existencia, bastando con la demanda a quien consta y actúa como el «titular del hogar familiar». STSJ. de Cataluña núm. 8156/2004, de 17 noviembre, rec. 6906/2004: Carece de legitimación pasiva la esposa del empleador en régimen de separación de bienes, que fue el que suscribió la oferta de empleo y lo contrató, con independencia de que aquélla pase mucho tiempo en la casa y sea la que confeccionase las nóminas. STSJ. de Cataluña núm. 4032/2005, de 4 mayo, rec. 3482/2004: Supuesto en
} 
parafamiliares el uso de esta fórmula de extinción es aun más difícil puesto que el art. 1.3 RD. 1620/2011, establece dos posibilidades: bien que el empleador sea el titular del domicilio o lugar de residencia, en cuyo caso su fallecimiento sí sería causa de extinción ${ }^{17}$; bien que sea un mero representante del grupo, en cuyo caso su muerte o incapacitación no provocaría la extinción de la relación ${ }^{18}$.

Por otra parte, y en los supuestos en que sobrevivan otros miembros de la familia al fallecimiento del empleador, la utilización de esta causa de extinción adquiere connotaciones particulares pues el "cese de la actividad" en estricto no podría venir exigido. En estos supuestos, de admitirse la extinción por tal causa, la dimensión personal de la relación adquiriría su máxima expresión. Y es probable que sea así, al menos en la interpretación que hacen por nuestros Tribunales ${ }^{19}$, pues daría más sentido

que no se cuestiona la calificación de la extinción de la relación a iniciativa de la viuda sino la indemnización por extinción por muerte del empleador pactada por su marido antes de fallecer éste; la subrogación por unos meses de la esposa no supone la pérdida del derecho a la indemnización, ni libera como responsables solidarios a los hijos del fallecido junto a la misma.

${ }^{17}$ Se aprecia cotitularidad de las dos ancianas fallecidas, madre e hija, dado que son atendidas ambas por la trabajadora, cotitulares de la vivienda (una como usufructuaria y otra como titular) y ambas se han reconocido como deudoras y comprometido al pago mediante legado o abono en metálico por el heredero (STSJ. de Galicia núm. 651/2015, de 28 enero, rec. 1866/2013). STSJ. de Asturias núm. 110/2018, de 23 enero, rec. 2872/2017: Con objeto de determinar quién es el empleador real, hay litisconsorcio pasivo necesario entre los hijos que actúan de empleadores y la madre que recibe los servicios en su domicilio, donde reside sola.

${ }^{18}$ No tiene condición de empleador ni procede el litisconsorcio pasivo, el familiar que acude todos los días a comer a casa del titular: STSJ. de Cataluña núm. 7980/2003, de 16 diciembre, rec. 463/2001. Tampoco tiene condición de empleador el sobrino, dueño de la casa donde vive con su tío, ambos ancianos. Por el contrario, es el tío el único empleador pues es el que contrata, paga y da órdenes a la trabajadora, sin que el sobrino haya tenido una intervención directa en la relación sino la de mero beneficiario de los servicios pese a ser el dueño-titular de la casa (STSJ. de Asturias núm. 1718/2014, de 12 septiembre, rec. 1498/2014). Como tampoco es empresaria la hermana de la empleadora, que convivían juntas en el hogar atendido por la trabajadora pues la $<<$ cotitularidad del hogar familiar no cabe inferirla, sin más, del hecho de que ... se beneficiara de los cuidados de la empleada de hogar, ... pues como ya se ha dicho, los servicios domésticos son los que se prestan "en o para la casa en cuyo seno se realizan", y están dirigidos, no sólo a la atención de la familia, entendida como tal, sino al cuidado de la comunidad de vida que la familia forma>> (STSJ. de Madrid núm. 963/2010, de 2 diciembre, rec. 3209/2010).

${ }^{19}$ GARCÍA VIÑA, J., cit, págs. 97 a 99. La subrogación es voluntaria y no se produce tácitamente dado que no se ha prestado servicios en los siete días siguientes al fallecimiento, sino que tan sólo acudió algún día a recoger sus enseres, en un supuesto en que la empleadora vivía sola y se extingue por su fallecimiento: STSJ. de C. Valenciana núm. 302/2006, de 31 enero, rec. 4205/2005. No hay relación laboral, pero, en cualquier caso, ésta se habría extinguido por el fallecimiento del titular, toda vez que su hijo no se subrogó en la relación ni ha prestado servicios para él: STSJ. Cataluña núm. 3043/2006, de 20 abril, rec. 8001/2005.

Sin embargo, sí aprecia subrogación en la extinción que se produce tras 14 días del fallecimiento del titular, respecto de su hija que convivía con él en el hogar: STSJ. de Andalucía/Sevilla núm. 238/2016, de 28 enero, rec. 324/2015. Hay sucesión entre anciana, ingresada en residencia de ancianos, y su hijastro, discapacitado psíquico, respecto de empleada de hogar contratada por administrador de los bienes de ambos: STSJ. de Islas Canarias/Las Palmas núm. 1339/2010, de 21 octubre, rec. 828/2010. También hay sucesión y cotitularidad de padre e hija, una vez fallecida la esposa y madre, respectivamente, de aquéllos y primera empleadora; la prestación de servicios durante los 21 días siguientes a la defunción dan lugar a la presunción legal de subrogación, sin que se haya acreditado que tal prestación de servicios estuviese motivada por la propia defunción: STSJ. de Cataluña núm. 7432/2016, de 16 diciembre, rec. 5874/2016. No cabe la extinción por fallecimiento al mes de producirse éste, pues aun siendo la relación laboral 
a la previsión de subrogación del art. 10 RD. 1620/2011, que es voluntaria para ambas partes. En caso contrario y a la vista de lo expuesto, parece que aun cuando el fallecimiento del empleador pueda ser causa de la extinción, ésta en principio quedaría limitada a los supuestos en que los cuidados del propio empleador fuesen el objeto principal del contrato, dejando en la incertidumbre jurídica o directamente al margen de su amparo los restantes supuestos en que efectivamente concurra su fallecimiento.

Y lo mismo sucedería en caso de extinción por incapacitación del titular, que puede ser tanto jurídica, es decir, declarada judicialmente, como natural o física, con efectos desde el momento de la comunicación de aquélla bien por el tutor, bien por el propio empleador o sus representantes si se trata de una incapacidad física. Repárese en el escaso margen de esta causa de extinción, nuevamente, desde la perspectiva del cumplimiento del requisito del cese de la actividad. Pues bien, aun tratándose de una tarea de cuidados, teóricamente podría plantearse como alternativa al desistimiento el cese en la actividad -también del empleador- derivada de una superior incapacidad física o psíquica de aquél para regir su persona, con, por ejemplo, ingreso en un plazo prudencial en una residencia ${ }^{20}$ o sustituido por la atención directa de sus familiares más cercanos. Nuevamente, con toda probabilidad por la incertidumbre jurídica, el grueso de estos supuestos se reconducen a la figura del desistimiento con el riesgo, caso contrario, de merecer la calificación de la improcedencia del despido por los defectos formales apreciados en dicha extinción. La incapacidad viene funcionando así, comúnmente y de manera similar al fallecimiento del empleador, más que como razón de extinción de la relación, la razón de la guarda o de la tutela, pasando a ser el guardador o tutor el que por razones diferentes a ésta, como pueda ser el referido ingreso en una residencia, decida el desistimiento de la relación o, por el contrario, la continuidad de la misma.

Finalmente, podría pensarse que tales causas son susceptibles de consignarse válidamente en el contrato de trabajo. Y nuevamente aparece un escollo pues en el común de los casos, y en particular y sobre todo en supuestos de enfermedades degenerativas, habrá que descartar que la decisión no dependa esencialmente de la voluntad del empleador ${ }^{21}$. Por tanto, las causas de extinción de la relación que con

personal y directa con el titular, se ha superado el plazo del art. 10 RD. 1620/2011, sin que se haya destruido la presunción mediante prueba de que su permanencia obedecía a realizar tareas propias del fallecimiento del empleador.

20 STSJ. de Cantabria núm. 504/2008, de 5 junio, rec. 471/2008: Es legítima la extinción contractual por decisión del tutor legal de la incapacitada y fundada en dicha causa de incapacidad civil, aun cuando fue ingresada meses antes de dicha declaración judicial en un geriátrico como medida cautelar y la extinción se produce dentro del lapso de los 60 días siguientes a la constitución de la tutela (art. artículo 262 del C Código Civil). Por otra parte, no cabe apreciar sucesión con el tutor legal (vid arts. 267 y 270 CCiv).

${ }^{21}$ En este sentido la STSJ. de Asturias núm. 2264/2015, de 27 noviembre, rec. 2282/2015, descarta la extinción por incapacidad del empleador e ingreso en residencia geriátrica, pues no cabe asimilar la incapacidad al ingreso en un centro geriátrico y no alcanza a probar que su situación no fuese incapacitante antes del ictus, dada la elevada edad de la empleadora (92 u 87 años) y las limitaciones que ello comporta. En cambio, la STSJ. de Cataluña núm. 3878/2002, de 16 mayo, rec. 8848/2001, acepta la extinción por incapacidad de la titular tras el ingreso de ésta en una residencia geriátrica a consecuencia de un agravamiento de su enfermedad de Alzheimer, con más de cinco años de la evolución, y pese a que la referida empleada atendía también a otros miembros de la unidad parafamiliar. 
mayor asiduidad podrían considerarse propias de su objeto o que pudiesen conferir una mayor seguridad jurídica son difícilmente aceptables y, en cualquier caso, presentan importantes dosis de incertidumbre.

\section{EL DESISTIMIENTO}

Presenta diferencias ostensibles frente a la extinción en el período de prueba que deberían excluir la aplicación de una idéntica doctrina respecto del art. 55.5 y 53.4 ET.

El desistimiento puede definirse, sencillamente, como la libertad de extinción indemnizada del vínculo laboral sin alegación de causa alguna. Tiene su fundamento en el derecho a la intimidad familiar y personal, así como en la inviolabilidad del domicilio (art. $18 \mathrm{CE}$ ) y al ser libre para el empleador tiene como únicos límites los derechos fundamentales (ej. art. 14 y $28 \mathrm{CE}$ ). Por otra parte, se trata de una vía de extinción especial de esta relación laboral que se suma a todas las demás -salvo las que hemos visto excluidas- y que por ser acausal puede hacer las veces de aquéllas siempre y cuando no se exprese causa coincidente con la de otra vía de extinción. Si ello fuese así nos situaríamos fuera de la figura o, al menos, surgiría una necesidad interpretativa de la voluntad del empleador para lo que sería imprescindible el cumplimiento de los requisitos formales del desistimiento (art. 11.3 RD. 1620/2011) que alcanzan, según veremos, un valor cuasiconstitutivo -aun discutido, antes de la reforma- o, en la actualidad, constitutivo.

En cambio, el período de prueba como pacto expreso y escrito, integrado en un contrato, constituye una condición resolutoria que faculta a ambas partes a resolver el contrato sin alegar justa causa, sin preaviso -salvo pacto en contrario-, sin exigencia formal alguna y sin indemnización. Su fundamento se encuentra en la libertad de empresa (art. 38 CE), que no es un derecho fundamental. El período de prueba, a diferencia del referido desistimiento, conlleva una completa excepción de los derechos derivados de la resolución de la relación laboral (art. 14.2 ET), y su posible alegación, por error o exceso, no socavaría los efectos de este armisticio pactado. Su razón jurídica es la de dotar a las partes de la posibilidad de un período experimental y, en particular al empleador, la comprobación de la aptitud del trabajador para el desempeño del puesto de trabajo e inserción del trabajador en la organización de la empresa. De ahí que se imponga la obligación de realizar las experiencias que constituyan el objeto de la prueba (art. 14.1 ET); como de la posibilidad de suspensión por acuerdo de las partes, en las situaciones de IT, riesgo durante el embarazo y la lactancia, suspensión por maternidad y conexos, y paternidad (art. 14.3 ET). En consecuencia, y pese a que el margen de desistimiento en el período de prueba es muy amplio en su construcción jurisprudencial cabe, a tenor de su finalidad, la posibilidad no sólo de afirmar su ilicitud por 
vulneración de derechos fundamentales, sino más allá, la de su consideración como abusivo, en particular por su duración excesiva como por ser ya conocidas sus capacidades profesionales por la empresa (art. 14.1 ET) ${ }^{22}$. Por último, la impugnación del desistimiento durante el período de prueba está sometido a caducidad de 20 días del despido $^{23}$, en tanto la reclamación de la indemnización y preaviso del desistimiento está sometido a plazo de prescripción de un año ${ }^{24}$.

A pesar de estas transcendentes diferencias entre ambas figuras, nuestros Tribunales vienen aplicando, con alguna relevante excepción ${ }^{25}$, la doctrina constitucional y jurisprudencia respecto del mismo supuesto en el período de prueba (SSTC 92/2008, 124/2009, 173/2013, y TS. 18-4-2011, rec. 2893/2010) ${ }^{26}$, en el caso de desistimiento del empleador durante el embarazo de la trabajadora o, por ejemplo, conectado con el descanso por maternidad ${ }^{27}$. Por tanto, en tales situaciones persiste la posibilidad ilimitada de desistimiento no discriminatorio. Y quiere decir esto que se tiene que demostrar y reconocer la discriminación; partiendo siempre de la prueba del conocimiento por el empresario del embarazo, si no se alcanza a reconocer la discriminación, el desistimiento será efectivo con independencia de que sea acausal, dado que tal doctrina mayoritaria viene negando la aplicación analógica del art. 55.5 ET o del 53.4 ET. Consideran, en definitiva, que dicha calificación de nulidad está prevista sólo respecto del despido causal y como alternativa al despido improcedente ${ }^{28}$.

\footnotetext{
${ }^{22}$ Vid: SEMPERE NAVARRO, A.V., "Sobre la terminación empresarial del contrato durante el período de prueba", Aranzadi Westlaw, BIB $2013 \backslash 2390$.

${ }^{23}$ STS. 11-5-1990.

${ }^{24}$ Por todas: STS. de 5 junio 2002, rec. 2506/2001.

${ }^{25}$ Aplican esta causa de nulidad objetiva del despido de la trabajadora embarazada, sin explicación de por qué no es desistimiento pese a cumplirse todos los requisitos formales del mismo y desconocerse el embarazo por parte del empleador: STSJ. Madrid, núm. 237/2019 de 6 marzo, rec. 822/2018; STSJ. de Madrid núm. 598/2016, de 26 septiembre, rec. 352/2016.

${ }^{26}$ Al respecto, véase, por ejemplo: QUINTANILLA NAVARRO, Y., "Extinción del contrato de trabajo durante el período de prueba y lesión de derechos fundamentales", Revista Española de Derecho del Trabajo num.164/2014 parte Comentario de Jurisprudencia, versión digital en BIB 2014\1074.

${ }^{27}$ No se pronuncia al respecto, dado que desestima el recurso por motivos formales: STS. núm. 987/2018 de 28 noviembre, rec. 3808/2016.

${ }^{28}$ En este sentido, entre otras muchas: STSJ. de Madrid núm. 714/2015, de 26 octubre, rec. 552/2015 pese a su conocimiento, no se aprecian indicios y, en cualquier caso, se alega causa económica$:<<$ sostiene en primer lugar la nulidad del despido con carácter "objetivo" con arreglo al art. 55.5 del Estatuto de los Trabajadores, por la mera condición de embarazada de la actora, tesis que ha sido rechazada por la sentencia de instancia con apoyo en la STC 173/13, que denegó recurso de amparo contra la sentencia del TS de 18-4-11 rec. 2893/10, que a su vez había confirmado la de esta Sala de Madrid (sección $1^{a}$ ) de 11-6-10 rec. 1357/10. De estas sentencias se infiere que la protección objetiva y reforzada respecto a la normativa comunitaria que el art. 55.5 del ET regula se refiere solamente al despido causal y no cabe apreciar analogía con el supuesto del desistimiento durante el período de prueba. Entendemos que esta misma solución de inaplicación de la analogía ha de utilizarse en el presente supuesto, rechazando que la previsión legal del art. 55.4 del ET claramente establecida para el despido causal, sea disciplinario u objetivo, se extienda al supuesto del desistimiento en la relación laboral de carácter especial del servicio del hogar familiar, que si bien exige ciertos requisitos de forma a diferencia del período de prueba, tiene en común con éste la característica de atenuación o excepción al principio de prohibición de libre extinción del contrato para el empresario.>>. En este sentido, también respecto de trabajadora del hogar, cuyo estado de gravidez desconocía el empleador: STSJ. de
} 
Ahora bien, si el desistimiento no es sino, entre otros, una alternativa a estos despidos objetivos, y si el desistimiento puede funcionar también como una opción al despido disciplinario cuya única finalidad es la de eludir la indemnización, no parece que esté justificada la negativa a la aplicación analógica del art. 55.5 y 53.4 ET. Es más, con esta doctrina se deja a un sector absolutamente feminizado como es éste con una tutela en derechos fundamentales muy inferior a la prevista respecto de la relación laboral común. Desprotección aun más evidente si se repara en que la inaplicación del art. 52 ET implica, a su vez, la protección frente al despido por ausencias derivadas de la maternidad, riesgo durante el embarazo, parto, lactancia y paternidad. En mi opinión, en este concreto ámbito la diferencia de trato no está justificada por la especialidad de la relación ni, consiguientemente, puede darse prevalencia al art. 18 CE sobre el 14 CE. En la pugna entre ambos, la consideración del art. 18 CE tendrá ahora suficiente campo en la imposibilidad de readmisión para el despido nulo.

Por el contrario, las mismas razones que alumbraron la necesidad de otorgar la tutela cualificada de los arts. 55.5 y 53.4 ET son más o, al menos, tan convenientes respecto de la empleada doméstica que, a más señas, carece de prestación de desempleo y hasta puede ver mermadas, en consecuencia, sus posibilidades de acceso a la prestación de maternidad, no ya por déficit de cotizaciones, sino por no encontrarse en situación asimilada al alta en el momento del parto (vid art. 4 RD. 295/2009) ${ }^{29}$

Ha sido mejorado en cuantía indemnizatoria y en seguridad jurídica en cuanto se han incrementado las exigencias formales e identificado los efectos de su incumplimiento. Tanto es así, que ahora puede defenderse que la forma del desistimiento es constitutiva.

El desistimiento se caracteriza frente a otras figuras extintivas, obviamente por su acausalidad, y materialmente por sus requisitos formales, los cuales con el RD. 1620/2011 se han incrementado y mejorado:

1. Se exige forma escrita en la que se deje constancia inequívoca de la voluntad de extinción por esta causa;

\footnotetext{
Andalucía/ Sevilla núm. 3064/2014, de 20 noviembre, rec. 2742/2013; STSJ. Extremadura núm. 383/2016, de 15 septiembre, rec. 338/2016; STSJ. de Cataluña núm. 688/2011, de 31 enero, rec. 5635/2010; STSJ. de Madrid núm. 143/2014, de 14 febrero, rec. 1834/2013. También, en esta línea en el caso un tanto particular en que el empleador desiste con conocimiento del embarazo de la trabajadora pero acredita causas ajenas al embarazo respecto de su desistimiento: STSJ. de Asturias núm. 1718/2014, de 12 septiembre, rec. 1498/2014. En dicho caso el desistimiento se considera con motivos fundados en la pérdida de confianza al comunicarle, junto con el embarazo, que sus condiciones de trabajo eran esclavistas y ellos unos explotadores, sin que se acreditase las condiciones de insalubridad en las que se supone que trabajaba, ni la jornada nocturna y las mentiras que en ella se vertían y el ultimátum amenazante de futuras denuncias. Tampoco hay vulneración de la garantía de indemnidad porque no se aprecia acto obligatorio preparatorio alguno de reclamación de derechos por parte de la actora ni denuncia posterior. También considera justificada la pérdida de confianza y lícito el desistimiento pese al conocimiento del estado de gestación de la trabajadora: STSJ. Madrid núm. 363/2015, de 21 abril, rec. 962/2014.

${ }^{29}$ El art. 14 del Convenio OIT 189 establece que las condiciones de acceso a las prestaciones de SS, incluida la de maternidad, no pueden ser más desfavorables que las del resto de trabajadoras.
} 
2. Para los contratos concertados con posterioridad a la entrada en vigor del RD. 1620/2011 (Disp. Transitoria 1 $1^{\mathrm{a}} .1$; 18-11-2011), una indemnización que se ha incrementado, pasando de 7 días naturales por año natural de servicio con el límite de 6 mensualidades, a los referidos 12 días con el máximo de 6 meses. Se equipara así, ahora como entonces, a la extinción por finalización de contrato temporal pero ahora sin remisión, asumida directamente en el art. 11.3 RD. 1620/2011 ${ }^{30}$

3. Un preaviso de 20 ó 7 días, según la relación haya superado o no el año -con una licencia de 6 horas semanales con el fin de buscar un nuevo empleo salvo que se trate de un trabajador a tiempo parcial ${ }^{31}$-. El preaviso, es susceptible de sustitución económica por los salarios tanto en metálico como en especie equivalentes a los días no respetados (art. 11.4 RD. 1620/2011). Por el contrario en el anterior 1424/1985 sólo se compensaba por los salarios en metálico, cambio que también se aprecia respecto de la indemnización.

4. Como he dicho antes, el desistimiento como fórmula de extinción acausal convive con las restantes vías de extinción de la relación, tanto indemnizadas como no indemnizadas. Para mayor dificultad, esta vía de extinción convive, asimismo, con la posibilidad de declaración de despido improcedente por defectos formales, como reconoce expresamente -igual que antes ex art. 10.1 RD 1424/1985- el art. 11.2 RD 1620/2011. Por consiguiente, el cumplimiento de los requisitos formales del desistimiento se erigen en un elemento fundamental en la delimitación respecto del resto y, muy en particular del despido improcedente. Veamos si ha habido cambios con el RD. 1620/2011.

Originariamente el TCT estableció una doctrina que fue seguida por la mayoría de los Tribunales Superiores de Justicia. Conforme a la misma, los requisitos formales del desistimiento carecían de carácter constitutivo. Se consideraba que el desestimiento era la figura principal de extinción de esta relación especial, con lo que si no se alegaba expresa y formalmente un incumplimiento -con el único objeto de eludir la indemnización- se presumía que era desistimiento y no despido improcedente ${ }^{32}$. El incumplimiento de los requisitos formales del desistimiento, en definitiva, la puesta a disposición de la indemnización y el preaviso, sólo abrirían la posibilidad de reclamación de tales cantidades adeudadas.

\footnotetext{
${ }^{30}$ Ahora la extinción por contrato temporal se remite implícitamente al ET por el art. 6.1 RD 1620/2011. Bajo el precedente RD estaba prevista en el art. 9.tres por remisión del 10.dos RD. 1424/1985 y ahora es asumida independientemente en el art. 11.3 RD. 1620/2011. esta indemnización incrementada se aplicará exclusivamente a los contratos que se celebren a partir de la fecha de entrada en vigor del RD. 1620/2011 (Disp. Transitoria $1^{\mathrm{a}}$.1) con lo que los anteriores mantendrán la indemnización de 7 días prevista en el derogado RD 1424/1985, no así su módulo de cálculo.

${ }^{31}$ Novedad criticada por un sector doctrinal dado que la jornada del trabajador a tiempo parcial puede ser muy amplia al ser la completa de 40 horas conforme al art. 9.1 RD 1620/2011 en relación con el art. 12.1 ET (CORDERO GORDILLO, V., "La relación laboral especial ...”, cit, pág. 79).

32 Véase, ampliamente: MENÉNDEZ SEBASTIAN, P., "Despido disciplinario o desistimiento empresarial en el trabajo al servicio del hogar familiar”, REDT, nº 119, págs. 695 y ss y en particular, págs. 698 a 703.
} 
Esta línea es corregida por las SSTS 5 junio 2002 (rec. 2506/2001) y 27 junio 2008 (rec. 2235/2007). El Tribunal Supremo niega tal presunción por carecer de base objetiva y trata de equilibrar la balanza entre las partes, de manera que el libre desistimiento del empresario tiene como contrapartida la seguridad jurídica del empleado; aun cuando los requisitos de puesta a disposición simultánea de la indemnización y disfrute de preaviso no sean constitutivos, sí se exige claridad en la comunicación de su elección por el desistimiento, y explícita o tácitamente el derecho a la correspondiente indemnización y preaviso. Como puede observarse, la labilidad de esta doctrina unificada ya está servida, pues la delimitación se hace descansar sobre la voluntad del empleador, que aun exigiendo claridad, admite un amplio margen de interpretación derivado incluso de actos concluyentes. Verdaderamente no cierra el paso a nada de forma clara; puede suprimirse la puesta a disposición simultánea, puede suprimirse el uso del término "desistimiento", puede suprimirse el preaviso... En cuanto a la exigencia de forma escrita, el TS parece querer apuntar a ello, pero sin atreverse a hacerlo abiertamente limitándose a exigir “comunicación” sin descartar, como decimos, su interpretación mediante actos coetáneos concluyentes.

En consecuencia, el seguimiento de esta doctrina por los TSJ ha sido formalmente unánime, con invocación por todos de su doctrina, pero muy dispar en la valoración de las exigencias formales y consecuencia de sus incumplimientos. Así, se aprecian sentencias que, en una misma línea de plena coherencia con la doctrina del Tribunal Supremo, subrayan la transcendencia y consiguiente improcedencia del despido por incumplimiento de los requisitos formales de comunicación escrita y ofrecimiento de indemnización $^{33}$; bien faltando la forma escrita, hacen hincapié en la falta de ofrecimiento de indemnización y preaviso ${ }^{34}$; bien a tenor de la valoración del conjunto de todos ellos, tanto uso del término desistimiento como del cumplimiento o no de los demás requisitos ${ }^{35}$.

\footnotetext{
33 STSJ. de Islas Canarias/Las Palmas núm. 1378/2011, de 17 octubre, rec. 816/2011.

34 STSJ. de Cataluña núm. 6105/2012, de 19 septiembre, rec. 3619/2012 -la empleadora comunica que no puede sostener económicamente el salario y que tendrá que buscarse otra ocupación, sin ofrecimiento de indemnización ni plazo de preaviso-. También en esta línea: STSJ. de Andalucía/Granada núm. 793/2010, de 17 marzo, rec. 205/2010; STSJ. de Galicia núm. 2765/2009, de 2 junio, rec. 1294/2009 -falta forma escrita, que días después se lleva a cabo pero sin ofrecimiento de indemnización-.

35 STSJ. de Andalucía/Granada núm. 1270/2011, de 11 mayo, rec. 747/2011: Si no se alega causa ni se usa el término desistimiento, ni puede deducirse de la cantidad abonada como indemnización -que no alcanza a la indemnización y preaviso- ni se da preaviso, no puede presumirse que se trata de un desistimiento sino que se trata de un despido improcedente. STSJ. de Galicia núm. 5502/2010, de 29 noviembre, rec. 719/2007: No puede calificarse de desistimiento, puesto que en ningún momento lo ha calificado como tal, ni puede extraerse inequívocamente de expresiones como la manifestación de prescindir de sus servicios $-<<\ldots$ es obligación del empresario definir inequívocamente si está llevando a cabo un despido o un desistimiento y el incumplimiento de esta obligación, supone que el acto extintivo deba calificarse como despido>>, sin que se haya puesto tampoco simultáneamente a disposición de la trabajadora la indemnización y preaviso. STSJ. de Andalucía/Málaga núm. 2012/2010, de 28 octubre, rec. 1056/2010: Es despido improcedente puesto que no lo ha formalizado, es verbal, y no ha puesto a disposición la indemnización y preaviso, sin identificación de incumplimiento alguno, siendo la indemnización la correspondiente, sin salarios de trámite. STSJ. de Madrid núm. 526/2007, de 23 julio,
} 
Hay otras que, en cambio, siguen en esencia las anteriores tesis del TCT en la que la falta de acusación es índice de interpretación de la voluntad de desistir, en tanto ninguno de los requisitos formales del desistimiento son constitutivos sino sus efectos y sólo abren la vía de su reclamación económica. En esta línea hay casos muy llamativos, como es el del STSJ. de Andalucía, Sevilla, núm. 1494/2009, de 14 abril, rec. 2270/2008, que admite el desistimiento del empleador aun cuando se limita éste a decirle a la trabajadora con carácter inmediato que la relación ha terminado y darle el dinero que le debe por los últimos diez días. Pese a su carácter verbal e inmediato y ni tan siquiera ofrecerse indemnización, considera que se trata una conducta concluyente de finalizar la relación sin causa disciplinaria, y ello con independencia de las acciones que correspondan para reclamar sus derechos sobre el preaviso o, en su caso, ante la Seguridad Social). También es significativa la STSJ. de Andalucía/ Sevilla, núm. 3064/2014 de 20 noviembre, rec. 2742/2013, en un caso de desistimiento verbal de trabajadora embarazada cuyo estado de gravidez se desconoce por el empleador, sin puesta a disposición de indemnización, pagándose exclusivamente el preaviso.

En la actualidad el legislador ha incrementado las exigencias formales y ha previsto las consecuencias del incumplimiento.

a. Como he anticipado, el art. 11.3 RD. 1620/2011 exige comunicación escrita en la que conste, de modo claro e inequívoco, la voluntad del empleador de dar por finalizada la relación laboral por esta causa. También exige como antes puesta simultánea de la indemnización, así como preaviso.

b. Ante la falta de forma escrita y en las condiciones de claridad expuestas y la puesta a disposición simultánea de la indemnización -salvo que la cuantía no se corresponda por error excusable- se presume que se ha optado por el despido y no por el desistimiento (art. 11.4 RD. 1620/2011).

c. Estos requisitos de forma y puesta a disposición simultánea de la indemnización son, en mi opinión, constitutivos en la medida en que se admite el despido improcedente por defecto formal y se establece una presunción iuris et de iure de que el empleador a optado por el despido y no por el desistimiento ${ }^{36}$. Verdaderamente el carácter de la presunción, que no admite de manera expresa prueba en contrario, no podría ser en puridad iuris tantum, dado que la admisión del despido improcedente por defecto de forma (art. 11.2.2 ${ }^{\circ}$ párr. RD 1620/2011) como se venía reconociendo también en el RD. 1424/1985, y la aplicación supletoria el Estatuto de los Trabajadores y la jurisprudencia conexa al mismo, revelan la imposibilidad de distinción real por otras vías. Por tanto, la seguridad jurídica y un mínimo equilibrio entre los sacrificios de ambas partes exige conferir a tales requisitos formales dicho

rec. 2635/2007: Despido verbal y no desistimiento, conforme a la doctrina del TS., pues se limita a decirle que ya no quiere que trabaje más para él.

${ }^{36}$ En contra, la considera iuris tantum: CORDERO GORDILLO, V., cit., pág. 80; MIÑARRO YANINI, M., cit, pág. 68 y en MIÑARRO YANINI, M., "La nueva regulación de la relación laboral de carácter especial del servicio del hogar familiar: una mejora mejorable (II)”, Relaciones Laborales, $\mathrm{n}^{\circ}$ 5, 2012, págs. 87 y 88. 
valor constitutivo ${ }^{37}$, tanto más en este contexto que pretende dar lógica a la convivencia de ambas figuras y a la luz de esa intención de acercamiento al régimen general de que hace gala el RD 1620/2011, tomando como modelo en este caso, el despido objetivo del art. 53 ET.. Y parece que el grueso de la doctrina judicial han aplicado la presunción sin más consideraciones que la atención a su incumplimiento. Así, la mayoría de las sentencias examinadas señalan que no cabe desistimiento verbal, exigiéndose indudablemente la forma escrita para el mismo ${ }^{38}$. También en aplicación del precepto reformado se aprecian sentencias que exigen con rigor tal puesta a disposición, declarando, caso contrario, la improcedencia del despido ${ }^{39}$. En cambio, también en

${ }^{37}$ En este sentido: LLANO SÁNCHEZ, M., "El nuevo contrato laboral especial del servicio del hogar familiar”, Actualidad Laboral, no 6, 2012, pág. 671.

${ }^{38}$ STSJ. de Madrid núm. 839/2012, de 11 octubre, rec. 3861/2012: no cabe desistimiento verbal decisión extintiva comunicada verbalmente con ofrecimiento de 45 días de indemnización-, por lo que procede su calificación como despido improcedente. Es despido improcedente y no desistimiento por defectos de forma: STSJ. de Valladolid núm. 12/2018, de 29 enero, rec. 596/2017; STSJ. de Cataluña núm. 7432/2016, de 16 diciembre, rec. 5874/2016; STSJ. de Madrid núm. 592/2014, de 30 junio, rec. 246/2014 -falta forma escrita, preaviso y puesta a disposición de la indemnización-; STSJ. de Castilla y León/Burgos núm. 237/2014, de 28 abril, rec. 221/2014 -falta de forma escrita con opción por desistimiento y puesta simultánea de indemnización en un supuesto en que se pretende la extinción por fallecimiento del titular habiéndose subrogado el hijo de aquél-.

${ }^{39}$ STSJ. de Galicia, núm. 4170/2018 de 8 noviembre, rec. 2425/2018: falta de claridad ante actuaciones contradictorias, con incumplimiento del deber de efectiva y simultánea entrega de la indemnización. STSJ. de Madrid núm. 200/2018, de 5 marzo, rec. 1256/2017 -cumplida la forma escrita y preavisado-: Las consecuencias del incumplimiento de la puesta a disposición de la indemnización no es otra que la de la presunción de que se ha optado por el despido. Aun cuando no se estimen por ser una cuestión planteada novedosamente en el recurso, las SSTSJ. de Asturias núm. 1381/2016, de 14 junio, rec. 1246/2016 y núm. 808/2016 de 19 abril, rec. 475/2016, afirman sintéticamente que <<Sin la comunicación escrita y el pago simultáneo de la indemnización no hay desistimiento sino despido >>. STSJ. de País Vasco núm. 842/2015, de 5 mayo, rec. 712/2015:<<el art.11.3 RD 1620/2011, de 14 de noviembre , exige la simultánea puesta a disposición del trabajador de la indemnización, y el abono íntegro de la misma en metálico (previsión que contraviene frontalmente la ley 7/2012 de 29 de octubre); en este caso no se hizo así, ni existió trasferencia bancaria, ni tampoco se señaló a la trabajadora que pasara a cobrarla ese mismo día por el domicilio de la empleadora pues de haber sido así podíamos valorar otra situación que es lo que pretende la recurrente, pero esto no ocurrió. La Juzgadora no ha considerado probado la existencia de requerimientos de la empleadora a la demandante, ese día u otros posteriores, para que acudiera a cobrarla a la vivienda, constando únicamente el ofrecimiento de pago en el acto de conciliación>>. También sobre puesta a disposición en el domicilio: STSJ. de Cataluña núm. 613/2018, de 30 enero, rec. 6121/2017: Se considera cumplido el requisito con la puesta a disposición de la indemnización en el domicilio que fue su centro de trabajo, sin que conste que a la trabajadora haya intentado retirar la misma y se le haya denegado el cobro, y sin que pueda exigirse transferencia en tanto el art. 11.3 RD 1620/2011 se refiere a "pago en metálico", aun cuando ante la pasividad o negativa a recibir la misma quepa consignación (art. 1176 CC). En mi opinión, la referencia del precepto al pago en metálico hay que contextualizarla en una relación en que el salario en especie es más frecuente, con lo que la indemnización debe suponer un cálculo en metálico de aquél sin posibilidad de compensaciones en especie, por lo que se reitera en el art. 11.2 RD. 1620/2011. Considera que hay puesta a disposición simultánea, si bien se negó a recibirla: STSJ. de Andalucía/Málaga núm. 508/2013, de 14 marzo, rec. 32/2013. Mucho más laxa, la STSJ. de Madrid núm. 292/2014, de 9 abril, rec. 1840/2013: Es desistimiento pues entiende cumplidos los requisitos formales del mismo. Por un lado, aunque no se usa el término desistimiento sí cabe deducir éste de la indemnización ofrecida en el documento de finiquito. También se considera cumplido el requisito de puesta a disposición simultánea pese a que no se hizo ni en el preaviso -verbal-, ni en el último día de prestación, que fue el momento en que se ofreció dicho finiquito, sino que se hizo mediante transferencia una semana después, al día siguiente en que la actora aceptó firmar -en día festivo- el referido documento. También en esta línea que flexibiliza el requisito de la simultaneidad del cobro: STSJ. de Madrid núm. 426/2013, de 10 junio, rec. 458/2013: Se considera 
correspondencia con el art. $53.4 \mathrm{ET}^{40}$, el art. 11.4 RD. 1620/2011 ha disminuido la transcendencia, no sólo de los errores excusables en el cálculo de la indemnización ${ }^{41}$, sino de la concesión del preaviso, que sólo supondrá <<la obligación del mismo de abonar los salarios correspondientes a dicho período o al pago de la indemnización en la cuantía correcta $>>^{42}$.

\section{EL DESPIDO DISCIPLINARIO MANTIENE UNA LÍNEA CONTINUISTA RESPECTO DEL ANTERIOR CON MEJORAS EN LA CUANTÍA DE LA INDEMNIZACIÓN}

El despido disciplinario tiene el régimen común estatutario en lo que se refiere a causas, forma y calificación. Por tanto, a diferencia del desistimiento, cabe su subsanación conforme al art. 55.2 ET (20 días sin readmisión), pero no en los 7 siguientes a la notificación de la sentencia puesto que no cabe readmisión (art. 110.4 LRJS). Es el despido improcedente el que presenta especialidades, que se mantienen y que han sido descifradas por la ya referida sentencia del Tribunal Supremo de 5 junio 2002. Como ya anticipamos en nuestro primer epígrafe, estas peculiaridades derivan de las particularidades del empleador, de manera que se presume una menor capacidad económica ni cabe imposición, ni aun por opción, de readmisión en el ámbito de la

cumplido el deber de puesta a disposición con la entrega al portero de la finca de la indemnización aun cuando no se llegue a entregar al tiempo de la recogida de sus enseres por representante al no solicitar éste la entrega de sobre alguno. No cabe exigir transferencia, pues no consta que conociese los datos bancarios de la trabajadora, ni tampoco puede exigirse que se conozca la posibilidad de consigna en el juzgado, al tratarse de un particular y no de una empresa.

En cambio, cumplidos los requisitos formales de comunicación escrita indicando que lo es por desistimiento e indemnización, no cabe presumir despido: STSJ. de Cataluña núm. 4417/2016, de 7 julio, rec. 3080/2016.

${ }^{40}$ MIÑARRO YANINI, M., op. cit, pág. 69.

41 STSJ. de Madrid núm. 426/2013, de 10 junio, rec. 458/2013. Y mantenido también por sentencias anteriores a la actual regulación: STSJ. de Cataluña núm. 5925/2007, de 13 septiembre, rec. 4151/2007: $<<$ La conclusión es pues que debe de resultar claramente la existencia de un desistimiento a efectos de no causar indefensión al trabajador respecto de sus consecuencias y la vía de su impugnación, y que ello solo puede producirse a través del cumplimiento genérico de los requisitos legales de aquél, que son los de la comunicación de cese sin imputación de faltas, el plazo de preaviso legal de 7 ó 20 días en función del tiempo trabajado y la puesta a disposición de la indemnización de 7 días por año, conforme al art. 10.2 del RD 1424/1985 ...tales requisitos no aparecen en la norma como un requisito ad solemnitatem, de modo que el incumplimiento de alguno de ellos, como es en el presente caso el importe puesto a disposición en concepto de indemnización, por tomarse como antigüedad una inferior, no convierte en despido lo que se manifestó con claridad que era un desistimiento, sino que permite en el plazo anual de prescripción solicitar la indemnización legal correspondiente >> [nota: en el burofax no habla de desistimiento, sino tan sólo de cese, pero sí de preaviso de 20 días e indemnización de 7 días en metálico puesta a su disposición].

En cambio, STSJ. de C. Valenciana núm. 847/2017, de 30 marzo, rec. 3830/2016: Es despido y no desistimiento pues considera cumplida la forma escrita mediante comunicación vía whatsapp, pero no la simultánea puesta a disposición de la indemnización aunque se le haya ofrecido otra cantidad.

42 STSJ. de Aragón núm. 586/2017, de 31 octubre, rec. 505/2017: hay desistimiento pues se cumplen los requisitos de forma escrita y entrega simultánea de la indemnización, con abono más tarde del correspondiente al preaviso. 
intimidad de éste y su familia ${ }^{43}$. En correspondencia, tampoco puede imponerse al empleado su readmisión, pues ese mismo carácter fiduciario de la relación puede considerarse legítimamente quebrado para el empleado ante un despido improcedente, y aun más si cabe, si éste es un trabajador interno, en cuyo caso también se vería afectado su derecho a la intimidad, inviolabilidad del domicilio y libertad de residencia (art. 19 CE). Por consiguiente, los efectos del despido improcedente son los siguientes:

a) La indemnización es inferior a la común, pues es equivalente a la que corresponde al despido objetivo procedente 20 días/año, prorrateados por meses los períodos inferiores al año -traslación que hizo la sentencia-, y máximo 12 mensualidades [frente a la de 33 días y 24 mensualidades]. La novedad que introduce el RD. 1620/2011 estriba en que ahora las indemnizaciones tanto por despido como por desistimiento, se calculan sobre el salario completo, en tanto antes se especificaba que se tomaría sólo el salario en metálico.

b) No hay derecho a salarios de tramitación, puesto que no están previstos en esta regulación del despido improcedente que, en interpretación jurisprudencial, descarta la aplicación supletoria del ET. La conservación de esta condición no es ya ninguna particularidad, puesto que la regla general es la de no conservación de los salarios de tramitación en la opción por la indemnización y, como hemos visto, aquí no hay posible opción por la readmisión.

En cuanto al despido nulo, persiste su vacío regulador, aun cuando hay consenso judicial respecto de que aquéllos tienen que ser necesariamente especiales, nuevamente, por ser imposible la condena de readmisión, tanto para el empresario como para el empleado. Es más, un sector de la doctrina ha llegado a negar la posibilidad de la declaración de de nulidad ${ }^{44}$, siendo sólo factible la improcedencia del despido y la indemnización del art. 11.2 RD. 1620/2011, como también otro acepta la declaración de nulidad pero con los efectos del despido improcedente específicos de esta relación especial $^{45}$, tanto en indemnización como en la ausencia de salarios de tramitación. Sin embargo, parece que la postura más correcta y por el momento mayoritaria es la de abrir la posibilidad de la declaración de nulidad del despido pero con los efectos indemnizatorios comunes con aplicación del art. 56 ET en relación tanto a la indemnización como a los salarios de trámite que ahora sí procederían calculados hasta

\footnotetext{
${ }^{43}$ Cuestiona la imposibilidad legal de opción por la readmisión y parece abogar por tal posibilidad, en tanto no está impuesta claramente por la norma, sino por la doctrina de suplicación -no así por el Tribunal Supremo-, dejando siempre abierta la facultad de que el empleador opte por la indemnización: STSJ. Andalucía/Sevilla, núm 411/2019, 13-2, rec. 117/2018.

${ }^{44}$ STSJ. de Madrid núm. 644/2016, de 17 octubre, rec. 517/2016 -trabajadora embarazada a la que se le deniega la nulidad objetiva del art. 55.5 ET-. También en esta línea, parece negar tal posibilidad la STSJ. Extremadura núm. 76/2012, de 22 febrero, rec. 634/2011.

${ }^{45}$ Esta es la opción de la STSJ. Extremadura núm. 383/2016, de 15 septiembre, rec. 338/2016, < < pues no existe razón jurídica que avale la aplicación del previsto en el artículo 56 del Estatuto de los Trabajadores, teniendo en cuenta el régimen especial de este tipo contractual >>. También en STSJ. de Andalucía/Málaga núm. 1983/2017, de 29 noviembre, rec. 1644/2017 -añadida la indemnización por vulneración de derechos fundamentales-.
} 
la fecha de la sentencia (arts. 110.1.a y b) y 286.2 LRJS) ${ }^{46}$ y, por supuesto, la correspondiente indemnización por vulneración de derechos fundamentales ${ }^{47}$.

\section{EL PUNTO MÁS DÉBIL Y CRITICABLE RADICA EN EL DESISTIMIENTO INDEMNIZADO DEL TRABAJADOR.}

Es en este campo, en el de la extinción unilateral por iniciativa del trabajador, donde considero que hay más trabajo por hacer, entre otras cosas porque no se regula el desistimiento indemnizado -que, en este caso no requiere de forma escrita, sino tan sólo de comunicación- salvo para el supuesto de cambio de localidad. Bien es verdad que podría considerarse implícito en la posible negativa del trabajador a ser subrogado del art. $10 \mathrm{RD}$ en caso de cambio de empleador, pero lo cierto es que no se reconoce expresamente dicha posibilidad y un sector doctrinal niega el desistimiento por tal causa $^{48}$. La interpretación alternativa de que el trabajador no pueda resistirse a la subrogación y deba mantener una actitud pasiva ante la opción que asuma el nuevo o potencial empleador debe ser descartada, puesto que el desequilibrio de las partes en la regulación del desistimiento en atención a esa especial relación personal sería manifiesto y, obviamente, mal podría hablarse de subrogación por $<<$ acuerdo $>>$. Pero desde luego, el art. 10.1 RD. 1620/2011 no facilita en absoluto el conocimiento de esa posibilidad por parte del trabajador, de manera similar a como sucedía respecto del caso de cambio de localidad del hogar familiar bajo la anterior regulación (art. 8.Dos RD. 1424/1985), antes de que se incorporase el $2^{\circ}$ apartado del art. 10.2 RD. 1620/2011 ${ }^{49}$.

Por otra parte, y pese a que ha sido interpretado por un sector doctrinal como equivalente a desistimiento, el incumplimiento grave de las condiciones de seguridad y salud laboral se reconoce como causa legitima de dimisión que debe ser, en mi opinión, encuadrable en la vía de extinción del art. 50 ET. Por consiguiente, considero que sólo sería aceptable el desistimiento fundado en esta causa como un medio menos exigente en beneficio de la prueba del trabajador.

\footnotetext{
46 STSJ. Madrid, núm. 237/2019 de 6 marzo, rec. 822/2018;STSJ. de Madrid núm. 598/2016, de 26 septiembre, rec. 352/2016; STSJ. País Vasco núm. 1968/2015, de 20 octubre, rec. 1736/2015; STSJ. de Madrid núm. 882/2016, de 26 octubre, rec. 614/2016; STSJ. de Cataluña núm. 286/2013, de 15 enero, rec. 6810/2012. No obstante, sin cuestionamiento de la cuantía indemnizatoria, reconoce que se adeudan los salarios de tramitación, no en aplicación de la normativa común, sino conforme a la forma de indemnizar por lesión de derecho fundamental dado que merece un reproche especial: STSJ de Castilla y León/Valladolid, 25 febrero 2013, rec. 2/2013.

47 STSJ. de País Vasco núm. 947/2014, de 13 mayo, rec. 864/2014, en un supuesto de despido nulo por acoso sexual.

${ }^{48}$ En este sentido: LLANO SÁNCHEZ, M., cit, pág. 668.

49 De hecho, un importante sector doctrinal consideró que bajo la anterior regulación el trabajador no podía desistirse en sentido estricto, es decir, con derecho a indemnización, ni tan siquiera por el traslado del hogar familiar a otra localidad, con lo que, en defecto de acuerdo, sólo le correspondería dicha facultad al empleador; el trabajador sólo podía dimitir, sin derecho a indemnización ni, probablemente, necesidad de preaviso (por todos: AYALA DEL PINO, C., cit, pág. 199; GARRIDO PÉREZ, E., cit, pág. 247; LÓPEZ GANDÍA, J./TOSCANI GIMÉNEZ, D., cit, 2006, pág. 44; MIÑARRO YANINI, M., cit, pág. 58).
} 
Es cierto que el trabajador, como cualquier otro, puede dimitir o abandonar sin indemnización el puesto de trabajo. También puede pretender extinguir su relación a través del despido indirecto del art. 50 ET. Pero estas vías no son suficientes en una relación de estas características y, desde luego requieren de adaptación. Piénsese que:

a. $\quad$ El art. 50 ET tiene un escaso margen de operatividad en esta relación. La inaplicación de los arts. 40 y 41 ET dejan en entredicho la aplicación del art. 50.1.a) ET (modificación sustancial de las condiciones de trabajo llevadas a cabo sin respetar el art. 41 ET y que redunden en menoscabo de la dignidad del trabajador); y parte del art. 50.1.c) ET (negativa del empleador a reintegrar al trabajador en sus anteriores condiciones de trabajo en los supuestos previstos en los arts. 40 y $41 \mathrm{ET}$, cuando una sentencia judicial los haya considerado injustificados). Como posible causa de extinción encuadrable en el art. 50 ET. quedaría sólo la falta de pago o retrasos y cualquier otro incumplimiento grave.

b. Como hemos anticipado, no son aplicables los arts. 40 y 41 ET con lo que, al menos a nivel teórico, los cambios tienen que ser siempre acordados. Sin embargo, no puede desconocerse el desequilibrio existente entre ambas partes como en cualquier otra relación laboral. Por consiguiente, ante unas ofertas inaceptables o que siendo sustanciales intenten de alguna manera imponerse en grave perjuicio al trabajador [como el art. $41 \mathrm{ET}$, en relación al tiempo de trabajo, régimen de trabajo a turnos, sistema de remuneración, cuantía salarial o funciones que excedan de la movilidad funcional] debería abrirse paso al desistimiento indemnizado ${ }^{50}$. De hecho es lo que viene a hacerse en el único supuesto en que se regulado, cual es la movilidad geográfica identificada con el cambio de localidad del hogar familiar.

c. $\quad$ Es más, debe considerarse que la relación fiduciaria y el ámbito íntimo en que se desenvuelve operan en un doble sentido. Precisamente por desarrollarse en una

\footnotetext{
${ }^{50}$ La STSJ. de Madrid núm. 615/2016, de 10 octubre, rec. 74/2016, aplica analógicamente el art. 10.2 RD. 1620/2011: hay derecho a extinción indemnizada en caso de desistimiento del trabajador por no aceptar la modificación de la jornada propuesta por escrito, que es pasar de 40 a 30 horas semanales en aplicación analógica al desistimiento del trabajador por cambio de localidad. La Disp. Adic. $2^{\mathrm{a}} \mathrm{RD}$ no prevé la evaluación de esta causa de extinción por el grupo de expertos, por lo que debe considerarse que conforme al régimen común de la extinción, las modificaciones sustanciales abren la posibilidad de extinción indemnizada por desistimiento del trabajador sin necesidad de reclamación judicial y confirmación de que la medida es correcta.

Parece no descartar de alguna forma una solución similar la STSJ. de C. Valenciana núm. 1714/2013, de 9 julio, rec. 1266/2013: Frente al argumento de que la trabajadora se vio obligada a desistirse de la relación ante la modificación sustancial propuesta, el TSJ declara que no puede entrar a valorar tales consideraciones al no quedar constancia en los hechos probados de cuáles eran aquéllas, destacando además que $<<$ No ignoramos la dificultad que conlleva la prueba de circunstancias de una relación como la de los empleados/as de hogar, cuya nueva regulación no ha conseguido paliar muchos de los defectos de su precedente, ni la indefensión en que queda la trabajadora si su empleador se niega a cumplir con las exigencias de un desistimiento del contrato, pues solo una mayor sensibilidad legislativa y judicial ante éstos supuestos podría subsanar los defectos probatorios que se observan en la práctica. $>>$.

Tampoco descarta abiertamente la aplicación del art. 41.3 ET en un supuesto de reducción unilateral de jornada de 30 a 18 horas semanales, si bien aprecia abandono de la trabajadora y no despido, tras discusión entre empleadora y empleada con entrega de llaves por ésta última: STS. de Madrid, núm. 25/2019 de 28 enero, rec. 755/2018.
} 
esfera de intimidad, los desencuentros entre ambas partes pueden colocar también al trabajador en una situación personal particularmente incómoda. De la misma manera que el empleador tiene derecho a preservar su espacio íntimo, tampoco el trabajador debería ser penalizado incondicionalmente por negarse a "invadir" o "someterse" al mismo. Con mayor claridad en el caso del trabajador interno estas consideraciones se acentúan por estar igualmente en juego su derecho a la intimidad. Sin embargo es común la apreciación judicial de abandonos en lugar de desistimiento tras discusiones en las que el empleado se va del domicilio, o tras ofrecimientos de condiciones que no son aceptadas por el trabajador. En mi opinión, y dadas las características de esta relación especial, carece de sentido que en una situación de conflicto en que el trabajador opta por irse y demandar posteriormente se aprecie sistemáticamente abandono salvo que lo "echen" de la casa ${ }^{51}$. No tiene sentido, como se ve en no pocos casos, forzar a la intervención de la policía. De la misma manera, tampoco se debería exigir continuación de la prestación si se usa la vía del art. 50 ET, sin necesidad de solicitar las medidas cautelares bajo los condicionantes del art. 79.7 y 180.4 LRJS. Quizá aquí, en correspondencia con el hecho de que no cabe readmisión, debería adaptarse la aplicación del precepto hasta el extremo de admitir que sea el trabajador el que extingue la relación y al juez corresponderle tan sólo la decisión de si la misma es indemnizada o no.

\section{BIBLIOGRAFÍA}

AYALA DEL PINO, C., "Cuestiones laborales de la relación laboral especial de servicio del hogar familiar”, Laborum, Murcia, 2005, págs. 215 y 216.

BARCELÓN COBEDO, S., "La relación laboral del servicio del hogar familiar tras el RD. 1620/2011, de 14 de noviembre”, Revista Doctrinal Aranzadi Social num.1/2012 parte Estudio, BIB 2012\512

CORDERO GORDILLO, V., "La relación laboral especial del servicio del hogar familiar”, Tirant lo Blanch, Valencia, 2014,

\footnotetext{
${ }^{51}$ Constituye un abandono, irse del domicilio tras la discusión y no volver al mismo para prestar servicios, en algunos de estos casos mediando intervención policial a instancia de la trabajadora o del empleador: STSJ. de Madrid núm. 307/2012, de 7 mayo, rec. 324/2012 -tras una discusión sobre su salario-. STSJ. de País Vasco núm. 157/2017, de 24 enero, rec. 2549/2016: Tras discusión con el nieto del empleador, que no vivía en la casa, hay dimisión, tanto por manifestaciones verbales en el sentido de que se marchaba de la casa, acompañada de actos inequívocos, como la retirada de sus enseres de la vivienda en la que trabajaba como interna, y la solicitud del abono de la liquidación por los servicios prestados. STSJ. de Cataluña núm. 7953/2013, de 5 diciembre, rec. 4235/2013: No hay despido sino abandono o dimisión tácita cuando tras una discusión con la mujer del empleador coge las maletas y se va, requiriéndole ambos el móvil y las llaves. STSJ. de Galicia núm. 5762/2010, de 15 diciembre, rec. 4007/2010: Hay abandono y no despido, pues la trabajadora no remitió durante el mes que estuvo de baja, los partes de baja a la empleadora. También considera que hay dimisión y no despido la STSJ. de San Sebastián núm. 284/2013, de 19 julio, rec. 218/2013: al darse de baja la trabajadora por propia voluntad tras la carta de despido, sin constancia de q ésta le fuese comunicada, ni su contenido. STSJ. de Madrid núm. 680/2011, de 24 octubre, rec. 4926/2011: Se considera probado en la instancia, conforme a la valoración que hace el juez, que la trabajadora abandona el puesto de trabajo antes de la fecha del desistimiento o despido previsto, teniendo que ingresar antes y en otra Residencia a la anciana.
} 
CRUZ VILLALÓN, J., "La aplicación de la Directiva sobre despidos colectivos", Temas Laborales, $\mathrm{n}^{\circ}$, 44, 1997

GARCÍA VIÑA, J., “Aspectos laborales de salud laboral y de Seguridad Social de los empleados del hogar”, Comares, Granada, 2009

GARCÍA VIÑA, J., “Aspectos laborales de salud laboral y de Seguridad Social de los empleados del hogar”, Comares, Granada, 2009.

GARRIDO PÉREZ, E., "El trabajo en el hogar: un replanteamiento de su especialidad desde el punto de vista normativo y jurisprudencial”, Mujer y Trabajo, Bomarzo, Albacete, 2003

LLANO SÁNCHEZ, M., "El nuevo contrato laboral especial del servicio del hogar familiar”, Actualidad Laboral, nº 6, 2012

LÓPEZ GANDÍA, J./TOSCANI GIMÉNEZ, D., "El nuevo régimen laboral y de Seguridad Social de los trabajadores al servicio del hogar familiar”, Bomarzo, Albacete, 2012

LÓPEZ GANDÍA, J./TOSCANI GIMÉNEZ, D., "Los trabajadores al servicio del hogar familiar. Aspectos laborales y de Seguridad Social. Propuestas de reforma”, Bomarzo, Albacete, 2006.

MIÑARRO YANINI, M., “El trabajo al servicio del hogar familiar: análisis de su nueva regulación”, REUS, Madrid, 2013

MIÑARRO YANINI, M., "La nueva regulación de la relación laboral de carácter especial del servicio del hogar familiar: una mejora mejorable (II)”, Relaciones Laborales, $n^{\circ}$ 5, 2012.

QUESADA SEGURA, R., “El contrato de servicio doméstico“, Madrid, La Ley, 1991

ROMERO MIRET, P., “La relación laboral especial y régimen de protección social del servicio del hogar”, Tesis doctoral, dir. García Ortega, J./Ruano Albertos, S., Universidad de Valencia, 2016

ROMERO MIRET, P., “La relación laboral especial y régimen de protección social del servicio del hogar”, Tesis doctoral, dir. García Ortega, J./Ruano Albertos, S., Universidad de Valencia, 2016.

SALA FRANCO, T., "La relación laboral especial del Servicio del Hogar Familiar y el contrato de trabajo doméstico”, Relaciones Laborales, 1986, Tomo I,

SEMPERE NAVARRO, A.V., "Sobre la terminación empresarial del contrato durante el período de prueba”, Aranzadi Westlaw, BIB 2013\2390 